\title{
Comparative studies of porous carbon nanofibers by various activation methods
}

\author{
Hye-Min Lee ${ }^{1,2}$, Hyo-Rang Kang ${ }^{3}$, Kay-Hyeok An ${ }^{1}$, Hong-Gun Kim ${ }^{2, \star *}$ and Byung-Joo Kim ${ }^{1, \star}$ \\ ${ }^{1}$ R\&D Division, Korea Institute of Carbon Convergence Technology, Jeonju 561-844, Korea \\ ${ }^{2}$ Department of Carbon Fusion Engineering, Jeonju University, Jeonju 560-759, Korea \\ ${ }^{3}$ Samsung Advanced Institute of Technology, Yongin 446-712, Korea
}

\section{Article Info}

Received 1 April 2013

Accepted 30 June 2013

*Corresponding Author

E-mail: kimbj2015@gmail.com

Tel: $+82-63-219-3720$

\section{Open Access}

DOI: http://dx.doi.org/

10.5714/CL.2013.14.3.180

This is an Open Access article distributed under the terms of the Creative Commons Attribution Non-Commercial License (http://creativecommons.org/licenses/ by-nc/3.0/) which permits unrestricted non-commercial use, distribution, and reproduction in any medium, provided the original work is properly cited.

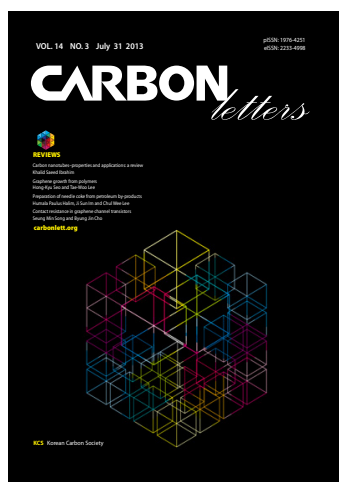

http://carbonlett.org

pISSN: $1976-4251$

eISSN: 2233-4998

Copyright $\odot$ Korean Carbon Society

\begin{abstract}
In this study, activated carbons nanofibers (ACNFs) were prepared from polyacrylonitrilebased nanofibers by physical $\left(\mathrm{H}_{2} \mathrm{O}\right.$ and $\left.\mathrm{CO}_{2}\right)$ and chemical $(\mathrm{KOH})$ activation. The surface and structural characteristics of the porous carbon were observed by scanning electron microscopy and X-ray diffraction, respectively. Pore characteristics were investigated by $\mathrm{N}_{2} / 77 \mathrm{~K}$ adsorption isotherms. The specific surface area of the physically ACNFs was increased up to $2400 \mathrm{~m}^{2} / \mathrm{g}$ and the ACNFs were found to be mainly composed of micropore structures. Chemical activation using $\mathrm{KOH}$ produced ACNFs with high specific surface area (up to $2500 \mathrm{~m}^{2} / \mathrm{g}$ ), and the micropores were mainly found in the ACNFs. The physically and chemically ACNFs showed both mainly type I from the International Union of Pure and Applied Chemistry classification.
\end{abstract}

Key words: various activation methods, activated carbons nanofibers, polyacrylonitrile, $\mathrm{KOH}, \mathrm{CO}_{2}, \mathrm{H}_{2} \mathrm{O}$

\section{Introduction}

Porous carbons, which have the collective name of activated carbon, have become more and more attractive materials for use in many adsorption and catalytic processes due to their high adsorptive capacity $[1,2]$. These carbons are prepared by physical activation (gasification of a char in oxidizing gases), or by chemical activation (carbonization of carbonaceous materials impregnated with chemical reagents). In addition to serving as an adsorbent, high porosity carbons have recently been used in the manufacture of high-performance double layer capacitors and lithium-ion batteries [3-5].

Activated carbon nanofibers (ACNF) are a microporous carbonaceous adsorbent developed from organic precursors either by physical or chemical activation. The advantages of ACNF are smaller fiber diameter (which minimizes diffusion limitations and allows rapid adsorption and desorption), more concentrated pore size distribution, and excellent adsorption capacity at low concentrations, in comparison with conventional activated granular or powdered carbons [6]. Typically, an ACNF is a microporous carbonaceous adsorbent exhibiting slit-shaped pores. This feature is the source of its high adsorption capacity. Factors affecting adsorption type are pore structure, surface chemistry, and adsorbent properties [714]. Basically, the type of porosity is mainly determined by the type of precursor employed; however, the method of activation is another parameter which may influence the final pore size distribution $[15,16]$. The properties of the ACNF are determined by the porous structure and pore surface chemistry, which are influenced by both the nature of the precursors and the method of activation. The methods of activation used to obtain porous carbon can be divided into two types, chemical and physical.

The physical activation method involves carbonization of the raw material and its subse- 
quent activation at high temperature in $\mathrm{CO}_{2}$ or $\mathrm{H}_{2} \mathrm{O}$ vapor [1720]. The chemical activation method involves the carbonization of a raw material previously impregnated with a chemical agent. A number of different, well-known chemical agents can be used in the chemical activation process, and among them, activation using $\mathrm{KOH}$ and $\mathrm{ZnCl}_{2}$ are two of the most used methods [21,22]. Chemical activation presents both advantages and disadvantages compared to physical activation. The main advantages are higher yield, lower temperature of activation, less activation time and generally, higher development of porosity [16,20]. Among the disadvantages, these activating agents are more expensive ( $\mathrm{KOH}$ and $\mathrm{ZnCl}_{2}$ vs. $\mathrm{CO}_{2}$ and $\mathrm{H}_{2} \mathrm{O}$ ) and an additional washing stage is also necessary. Moreover, these hydroxides are very corrosive. In fact, physical activation with $\mathrm{CO}_{2}$ or $\mathrm{H}_{2} \mathrm{O}$ is the usual procedure to obtain ACNF.

The pore structure of the porous carbons will largely depend on the activation methods. In order to make clear the influence of activation methods on pore development of porous carbons, we measured the specific surface areas of all the porous carbons prepared from polyacrylonitrile (PAN) using different activation methods.

Using different activation methods, samples with various porestructures can be obtained. So it is of great importance to investigate the differences in porous structure caused by different activation methods with the aid of adsorption measurement [23].

In this study, we investigated differences in the porous structure of ACNFs prepared from a single precursor (PAN), but by different activation methods including physical and chemical activation; using low-temperature nitrogen adsorption over a wide range of relative pressures.

\section{Experimental}

\subsection{Sample preparation}

PAN-based ACNFs with various degrees of activation were prepared in our laboratory using different activation agents (i.e., $\mathrm{H}_{2} \mathrm{O}, \mathrm{CO}_{2}$, and $\mathrm{KOH}$ ). The stabilized nanofibers were transferred to a quartz tube $(1300 \times 127 \mathrm{~mm})$ in a tube furnace for carbonization under nitrogen at $1000^{\circ} \mathrm{C}$ for $2 \mathrm{~h}$ using the heating rate of $5^{\circ} \mathrm{C} / \mathrm{min}$.

\subsection{1. $\mathrm{KOH}$ activation}

Chemical activation of the CNFs was performed using $\mathrm{KOH}$ as the chemical reagent. The CNFs were immersed in each $\mathrm{KOH}$ solution (4 M) respectively for $30 \mathrm{~min}$. The mixture was dried at $80^{\circ} \mathrm{C}$ for $12 \mathrm{~h}$, before heating at $5^{\circ} \mathrm{C} / \mathrm{min}$ under $\mathrm{N}_{2}(200 \mathrm{~mL} / \mathrm{min})$ to a selected temperature $\left(850^{\circ} \mathrm{C}\right)$, using the apparatus and procedure described for chemical activation; with a reaction time of $30 \mathrm{~min}$. To remove the potassium, hydrochloric acid $(0.5 \mathrm{M})$ was added to the mixture for $30 \mathrm{~min}$, before filtering and washing with distilled water until the $\mathrm{pH}$ of the filtrate reached $\mathrm{pH} 6$. The CNFs were dried at $100^{\circ} \mathrm{C}$ for $24 \mathrm{~h}$.

\subsection{2. $\mathrm{CO}_{2}$ activation}

$\mathrm{CO}_{2}$ activation was performed in the same quartz tube with the carbonization. The $\mathrm{CNFs}$ were heated $\left(5^{\circ} \mathrm{C} / \mathrm{min}\right)$ to the required reaction temperature $\left(1000^{\circ} \mathrm{C}\right)$ under $\mathrm{N}_{2}(500 \mathrm{~mL} / \mathrm{min})$, before the $\mathrm{N}_{2}$ was switched to $\mathrm{CO}_{2}(500 \mathrm{~mL} / \mathrm{min})$ for a reaction time of $1 \mathrm{~h}$. The sample was then allowed to cool under $\mathrm{N}_{2}(500$ $\mathrm{mL} / \mathrm{min})$.

\subsection{3. $\mathrm{H}_{2} \mathrm{O}$ activation}

For $\mathrm{H}_{2} \mathrm{O}$ activation, a stainless steel tube with fixed amount of steam-feed was used. All other conditions were same as that for $\mathrm{CO}_{2}$ activation. The $\mathrm{CNFs}$ were heated $\left(5^{\circ} \mathrm{C} / \mathrm{min}\right)$ to the required reaction temperature $\left(900^{\circ} \mathrm{C}\right)$ under $\mathrm{N}_{2}(500 \mathrm{~mL} / \mathrm{min})$, before the $\mathrm{N}_{2}$ was switched to $\mathrm{H}_{2} \mathrm{O}(2 \mathrm{~g} / \mathrm{min})$ for a reaction time of $1 \mathrm{~h}$. The sample was then allowed to cool under $\mathrm{N}_{2}(500 \mathrm{~mL} / \mathrm{min})$.

\subsection{Characterizations}

Nitrogen adsorption isotherms of CNFs and their activated forms were measured with BELSORP-max (BEL JAPAN, Japan) at liquid nitrogen temperature. All samples were degassed at $300^{\circ} \mathrm{C}$ for $6 \mathrm{~h}$ prior to the measurements. The specific surface area was calculated in the relative pressure interval of 0.04-0.2 using the Brunauer-Emmett-Teller (BET) method [24]. Pore size and distribution were calculated by the Barrett-Joyner-Halenda (BJH) method from desorption curves [25]. Microstructural differences between pure CNF and ACNF were determined using a wide-angle X-ray diffractometer (WAXRD), employing a Rigaku SmartLab X-ray diffractor with a customized automount and a $\mathrm{Cu} \mathrm{K} \alpha$ radiation source. Diffraction patterns were collected within the diffraction angles from $10^{\circ}$ to $90^{\circ}$ with a speed of $2 \% \mathrm{~min}$. The morphology and diameter of the CNF, AC$\mathrm{NF}-\mathrm{KOH}, \mathrm{ACNF}-\mathrm{CO}_{2}, \mathrm{ACNF}-\mathrm{H}_{2} \mathrm{O}$, and PAN precursor nanofibers, and their stabilized and carbonized nanofiber forms, were explored using a field emission scanning electron microscope (JSM 6701-F, JEOL, Japan). In order to reduce charging during scanning electron microscopy (SEM) imaging, samples were first placed on a sample holder and coated with platinum. Diameter distributions of the nanofibers were determined measuring 50 nanofibers from different regions of each SEM image.

\section{Results and Discussion}

In order to gain an understanding on the influence of activation methods on the pore structure of ACNFs, the porous structure of various carbons had to be determined. Fig. 1 shows the typical $\mathrm{N}_{2}$ adsorption/desorption isotherms for all the ACNFs prepared in this work. There are six kinds of adsorption isotherm according to the International Union of Pure and Applied Chemistry (IUPAC) classification, and each is indicated by a distinct pore structure. Because the adsorption isotherms of $\mathrm{N}_{2}$ at $77 \mathrm{~K}$ contain a large amount of information related to pore structure, and because changes in them imply alteration of pore structures, their measurements are the basis from which to estimate the pore-structure parameters. Every curve is classified as type I by the IUPAC classification. However, there are differences in pore-structures between the samples. Each graph has a point of inflection called a 'knee' around $\mathrm{P} / \mathrm{P}_{0}(0.1)$. This point indicates that monolayer adsorption is complete, so it is possible to calculate specific surface area at this point using the BET equation. Over $\mathrm{P} / \mathrm{P}_{0}(0.1)$, the adsorbed volume was increased predominantly, which means that there are also mesopores on CNFs. 
Typically, treatments for chemical activation require lower temperatures than for physical activation, to cause the precursor to develop an equal amount of new porosity. In this paper, $850^{\circ} \mathrm{C}$ was selected as the treatment temperature for $\mathrm{KOH}$ activation. It confirmed by the $\mathrm{N}_{2}$ adsorption/desorption isotherms (Fig. 1). It resembles the IUPAC type I isotherm indicating micropore domination inside the material. In $\mathrm{KOH}$ activated samples, mi-

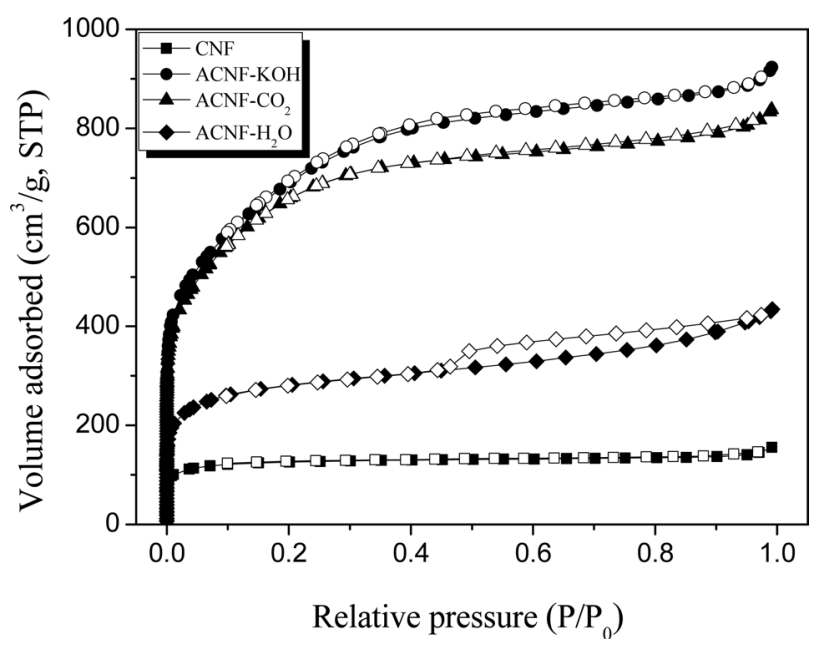

Fig. 1. $\mathrm{N}_{2} / 77 \mathrm{~K}$ adsorption-desorption isotherm curves of activated carbon nanofibers (ACNFs) as a function of activation methods. cropores made up more than $51 \%$ of the total porosity.

In general, activation using physical methods requires high temperatures to develop sufficient internal porosity. In this paper, 900 and $1000^{\circ} \mathrm{C}$ heat treatments were chosen to use with $\mathrm{CO}_{2}$ and $\mathrm{H}_{2} \mathrm{O}$ activation. Normally, $\mathrm{CO}_{2}$ activation produces activated carbon with well- developed micro-porosity. This characteristic is observable from the nitrogen isotherms (Fig. 1) as they resemble the IUPAC type I isotherm indicating micropore domination inside the material. The development of mesoporosity is also observable from the increase of the slope of nitrogen adsorption isotherm curve in the large $\mathrm{P} /$ Po region, and the appearance of desorption hysteresis. The textural properties summary of the $\mathrm{CO}_{2}$ activated samples is provided in Table 1. In the $\mathrm{CO}_{2}$ activated samples, micropores amounted to more than $59 \%$ of the total porosity.

Meanwhile, $\mathrm{H}_{2} \mathrm{O}$ activation produced highly mesopore-rich activated carbons. It is interesting to note that $\mathrm{H}_{2} \mathrm{O}$-activated samples showed clear hysteresis in the desorption curve. It indicates that largely developed pores in $\mathrm{H}_{2} \mathrm{O}$-activated CNF are pot-like structures.

The yield of porous carbons varies according to different activation methods for PAN. It can be seen from Table 1 that $\mathrm{CO}_{2}$ provided higher yields of porous carbon than other methods. Compared with $\mathrm{CO}_{2}$ activation, in the same activation time, $\mathrm{H}_{2} \mathrm{O}$ activation provided both inferior porosity development and lower yield.

The BJH method was used for determination of pore size dis-

Table 1. Textural properties of ACNFs as a function of activation method

\begin{tabular}{cccccccc} 
& Yield $(\%)$ & $\mathrm{S}_{\mathrm{BET}}\left(\mathrm{m}^{2} / \mathrm{g}\right)$ & $\mathrm{V}_{\text {Total }}\left(\mathrm{cm}^{3} / \mathrm{g}\right)$ & $\mathrm{V}_{\text {Meso }}\left(\mathrm{cm}^{3} / \mathrm{g}\right)$ & $\mathrm{V}_{\text {Micro }}\left(\mathrm{cm}^{3} / \mathrm{g}\right)$ & $\mathrm{D}_{\mathrm{p}}(\mathrm{nm})$ \\
\hline $\mathrm{CNF}$ & 36 & 480 & 0.24 & 0.06 & 0.18 & 2.00 \\
\hline $\mathrm{ACNF}-\mathrm{KOH}$ & 5 & 2500 & 1.42 & 0.69 & 0.73 & 2.28 \\
\hline $\mathrm{ACNF}_{-} \mathrm{CO}_{2}$ & 16 & 2400 & 1.29 & 0.53 & 0.76 & 2.16 \\
\hline $\mathrm{ACNF}-\mathrm{H}_{2} \mathrm{O}$ & 10 & 1040 & 0.67 & 0.32 & 2.56 \\
\hline
\end{tabular}

ACNFs: activated carbon nanofibers, $\mathrm{S}_{\mathrm{BE}}$ : specific surface area calculated using Brunauer-Emmett-Teller (BET) equation at a relative pressure range of 0.04-0.2.

$\frac{P}{v\left(P_{0}-P\right)}=\frac{1}{v_{m} c}+\frac{c-1}{v_{m} c}\left(\frac{P}{P_{0}}\right)$

$V_{\text {Total }}$ total pore volume is estimated at a relative pressure $P / P_{0}=0.990$.

$V_{\text {Meso: }}$ mesopore volume determined from the subtraction of micropore volume from total pore volume.

$\mathrm{V}_{\text {Micro: }}(\mathrm{DR}): \log _{10} V=\log _{10} V_{P}-C^{\prime} \log _{10}^{2}\left(\frac{P_{0}}{P}\right), C^{\prime}=2.303\left(\frac{R T}{\varepsilon}\right)^{2}$.

$\mathrm{D}_{\mathrm{p}}$ : average pore diameter. $\mathrm{d}=\frac{4 \times V}{A}$

Table 2. Structural parameters of the ACNFs as a function of activation method

\begin{tabular}{ccccccccc} 
& \multicolumn{3}{c}{002 peak } & \multicolumn{4}{c}{$10 l$ peak } \\
\cline { 2 - 9 } & $2 \theta\left({ }^{\circ}\right)$ & $\mathrm{d}_{02}(\AA)$ & FWHM $(2 \theta)$ & $\mathrm{L}_{\mathrm{c}}(\AA)$ & $2 \theta\left({ }^{\circ}\right)$ & $\mathrm{d}_{10 l}(\AA)$ & FWHM $(2 \theta)$ & $\mathrm{L}_{\mathrm{a}}(\AA)$ \\
\hline $\mathrm{CNF}$ & 20.2 & 4.39 & 10.51 & 7.68 & 43.92 & 2.06 & 5.34 & 32.8 \\
$\mathrm{ACNF}-\mathrm{KOH}$ & 19.5 & 4.55 & 8.52 & 9.47 & 43.60 & 2.07 & 8.06 & 21.7 \\
$\mathrm{ACNF}-\mathrm{CO}_{2}$ & 19.7 & 4.50 & 9.08 & 8.89 & 43.77 & 2.07 & 5.89 & 29.7 \\
$\mathrm{ACNF}-\mathrm{H}_{2} \mathrm{O}$ & 19.5 & 4.55 & 8.93 & 9.03 & 43.34 & 2.09 & 4.94 & 35.4 \\
\hline
\end{tabular}

ACNFs: activated carbon nanofibers, FWHM: full width at half maximum. 


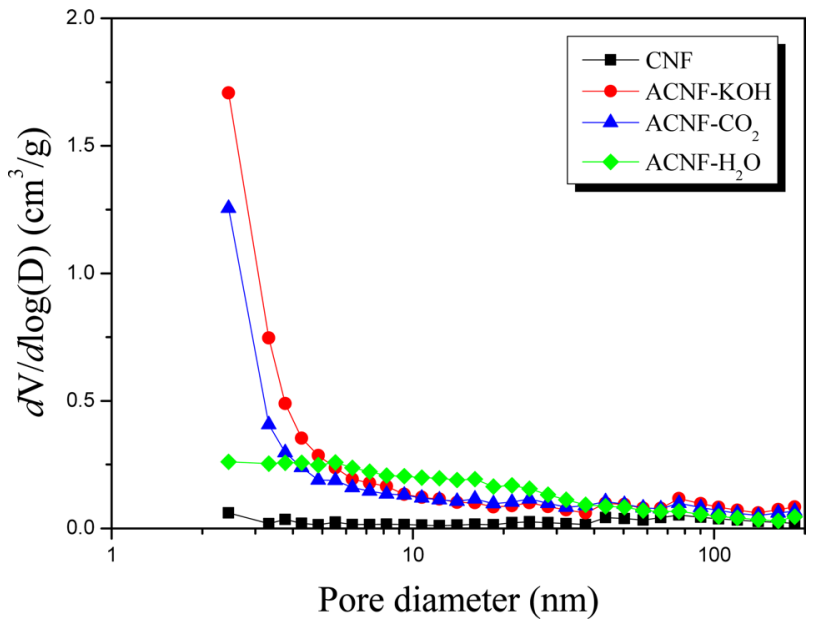

Fig. 2. Pore size distribution of activation carbon nanofibers (ACNFs) with different activation methods calculated by a Barrett-Joyner-Halenda equation.

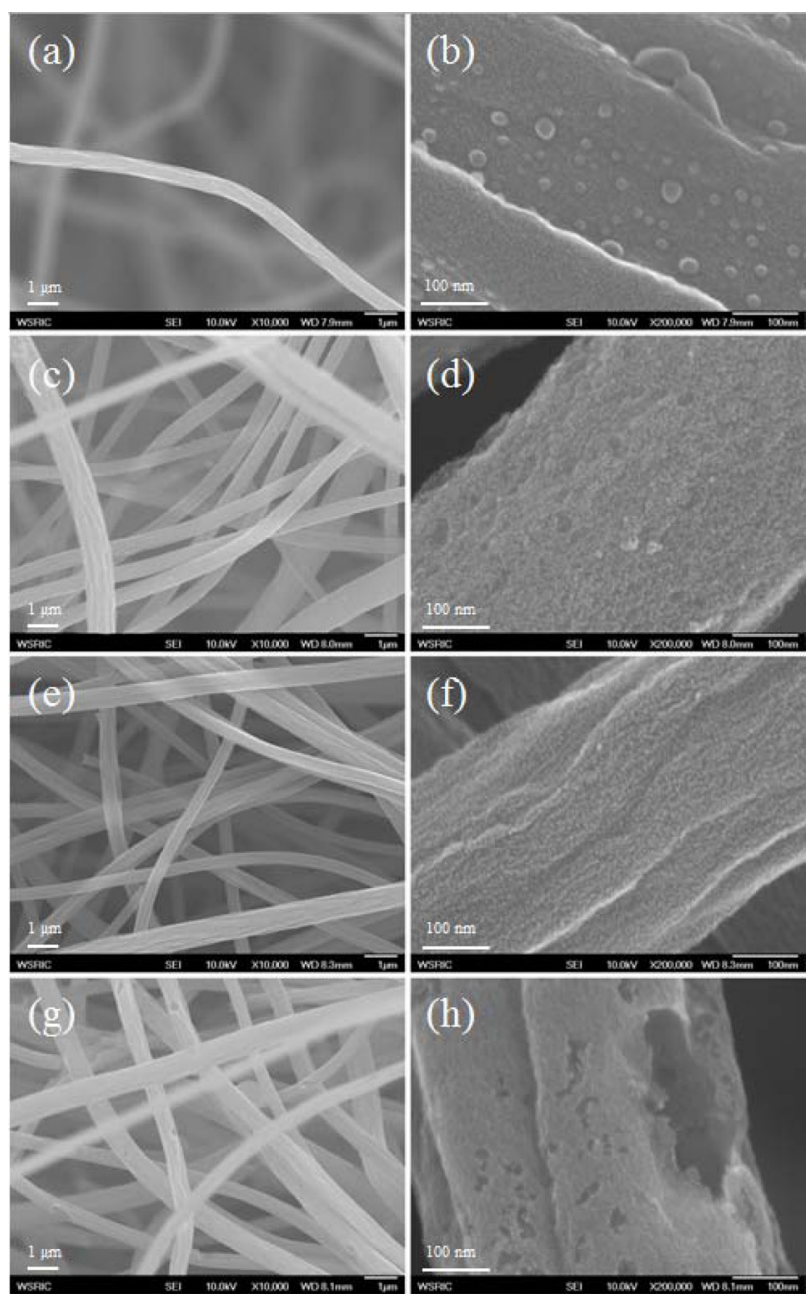

Fig. 3. Scanning electron microscopy micrographs of carbon nanofibers (CNFs): (a) and (b): low and high magnification of CNF; (c) and (d): low and high magnification of activated CNF (ACNF)-KOH; (e) and (f): low and high magnification of ACNF- $\mathrm{CO}_{2} ;(\mathrm{g})$ and $(\mathrm{h})$ : low and high magnification of ACNF- $\mathrm{H}_{2} \mathrm{O}$; low magnification: $\times 10 \mathrm{k}$; high magnification: $\times 100 \mathrm{k}$. tribution. Integrating the data of the desorption isotherm with the computation of pore size, 1.7-300 $\mathrm{nm}$ mesopore pore-sizedistribution of prepared activated carbon was calculated by the BJH theory. Fig. 2 illustrates the variation of BJH accumulation pore volume and differential pore volume of prepared ACNFs followed by transitional pore diameters. It can be seen, from from $\mathrm{ACNF}-\mathrm{KOH}$ and $\mathrm{ACNF}-\mathrm{CO}_{2}$, that $\mathrm{BJH}$ accumulation pore volume and differential pore volume decreased gradually with an increase in pore diameter, and whereafter the curve tended to be a level when the pore diameter exceeded $10 \mathrm{~nm}$. ACNF-KOH and $\mathrm{ACNF}-\mathrm{CO}_{2}$ exhibited complex pore systems consisting of not only the particular pores around $1.8 \mathrm{~nm}$, but also a large number of other-sized pores in a wide range from 1-10 nm.

The microstructures of the prepared CNFs and ACNFs are shown in Fig. 3. For the CNFs, the surface was typically very smooth, without any pores, but with some uneven surfaces. After $\mathrm{KOH}$ impregnation and activation at $850^{\circ} \mathrm{C}$ under $\mathrm{N}_{2}$ atmosphere, the surface of ACNF-KOH became rough and many pores appeared on it. Small pores, transitional pores, and large pores of different shapes are shown in this micrograph. It was reported that $\mathrm{KOH}$ impregnation had important effect by increasing the specific surface area and by generation of micropores. In Fig. 3, the KOHactivated fibers display a lot of holes, seen even in the SEM image, but these were not visible on the physically activated fibers.

SEM images of all types of ACNFs are shown in Fig. 3, which shows the pores and cracks on the surface developed due to activation. The average pore size of $\mathrm{ACNF}-\mathrm{CO}_{2}, \mathrm{ACNF}-\mathrm{KOH}$, and $\mathrm{ACNF}-\mathrm{H}_{2} \mathrm{O}$ increased in this order.

The average diameters of the ACNFs obtained from this experiment were estimated by ImageJ software (JEOL, Japan); installed in the SEM apparatus. As can be seen in Fig. 4, the PAN-nanofiber diameter is relatively uniform $(700-800 \mathrm{~nm})$. The diameters of the PAN nanofibers decreased slightly during carbonization and activation. The average diameter of the CNF samples was about $800 \mathrm{~nm}$. After activation, the average diameter of ACNFs considerably decreased. In the case of $\mathrm{KOH}$ and $\mathrm{H}_{2} \mathrm{O}$ activation, the average diameter of the ACNFs had a range from 300 to $400 \mathrm{~nm}$, and for $\mathrm{CO}_{2}$ activation, the diameters showed the size from 400 to $500 \mathrm{~nm}$.

The XRD patterns of the ACNFs prepared by different activation methods using $\mathrm{Cu} \mathrm{K} \alpha$ radiation are shown in Fig. 5. ACNFs are usually amorphous carbon composed of random microcrystalline carbon fragments. Generally, they are composed of three kinds: graphite-like microcrystals, single-reticular-plane carbon and non-organized carbon. These ACNFs exhibit very broad diffraction peaks and the absence of a sharp peak reveals a predominantly amorphous structure. Thus, the ACNF obtained can be identified as carbon with an amorphous structure. There are massive microcrystals with turbostratic graphite structure in the prepared ACNFs. The two obvious diffraction peaks represent, respectively, the diffraction-characteristic peaks of the microcrystalline (002) and (101) crystal face of the turbostratic graphite structure of the ACNF. It can also be seen from Fig. 5, in the diffraction spectrum of the ACNF prepared during this work, its microcrystalline (002) crystal face appears at $2 \theta=19.5^{\circ}, 19.7^{\circ}$, while for commercial ACNF, the microcrystalline (002) crystal face appears at $2 \theta=20.2^{\circ}$. That is to say, the diffraction angle of (002) the crystal face of ACNF is smaller than that of CNF. From the Bragg equation $(2 \mathrm{~d} \sin \theta=n \lambda)$, we can see that plane 

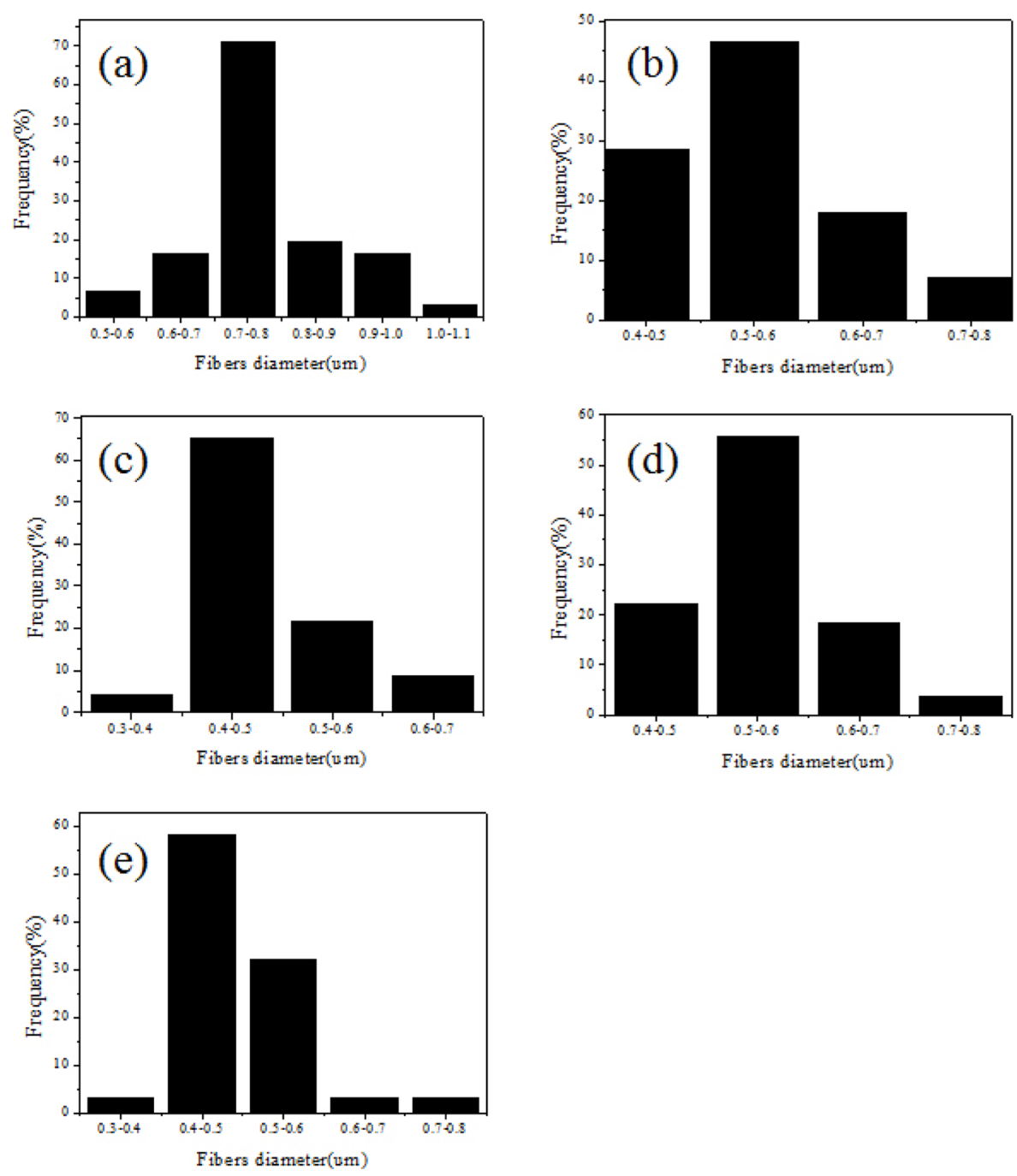

Fig. 4. Diameter distribution of electrospun carbon nanofibers (CNFs) with additive contents: (a) polyacrylonitrile nanofibers, (b) $\mathrm{CNF}$, (c) activated $\mathrm{CNF}$ (ACNF)-KOH, (d) ACNF-CO ${ }_{2}$, (e) ACNF- $\mathrm{H}_{2} \mathrm{O}$

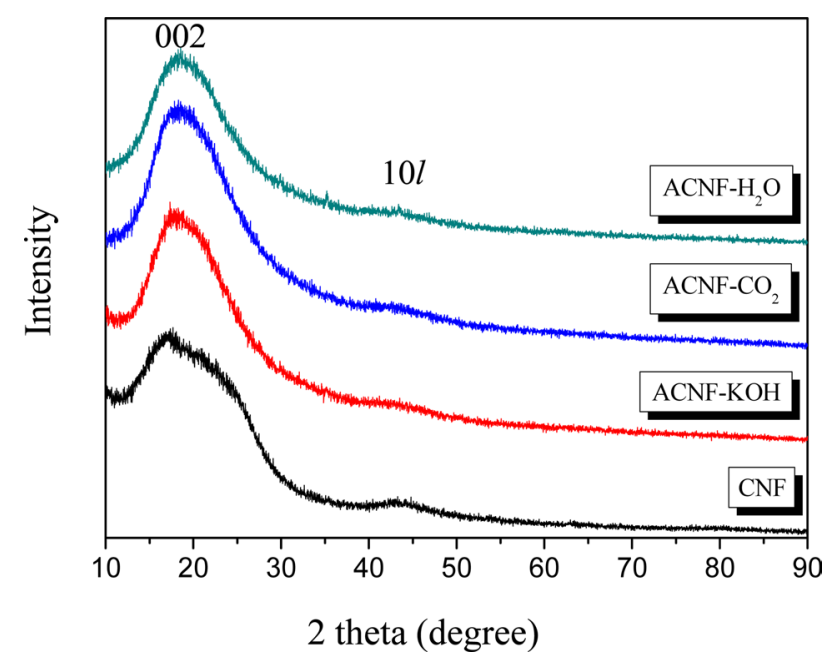

Fig. 5. X-ray diffraction patterns of activated carbon nanofibers (ACNFs) produced by different activation methods. spacing d (002) of the diffraction crystal face (002) for ACNF is relatively larger, indicating that the turbostratic degree of the experimental ACNF is relatively apparent.

\section{Conclusions}

ACNFs with surface area around 1000-2500 $\mathrm{m}^{2} / \mathrm{g}$ have been produced from PAN by activation with $\mathrm{CO}_{2}, \mathrm{H}_{2} \mathrm{O}$ and $\mathrm{KOH}$. Carbonization was conducted at $1000^{\circ} \mathrm{C}$ for $2 \mathrm{~h}$ in nitrogen gas. ACNFs were prepared by electrospinning to get high specific surface area and pore volume during various kinds of activation. The average diameter of as-spun PAN nanofibers was observed to be in the range of 700 to $800 \mathrm{~nm}$, and it changed to the size in the range of 500-600 nm after carbonization. After activation, the average diameters of all ACNFs are considerably decreased. In the case of activation by $\mathrm{KOH}$ and $\mathrm{H}_{2} \mathrm{O}$, the average diameter of ACNFs had a range from 300 to $400 \mathrm{~nm}$; with 400 to $500 \mathrm{~nm}$ for those from $\mathrm{CO}_{2}$ activation. Textural properties containing specific surface area and pore volume of the ACNFs showed different features. In 
the cases of $\mathrm{KOH}$ and $\mathrm{CO}_{2}$ activation, specific surface area was over $2400 \mathrm{~m}^{2} / \mathrm{g}$ and micropore volume was greater than $0.7 \mathrm{cc} / \mathrm{g}$. However, ACNF activated by $\mathrm{H}_{2} \mathrm{O}$ showed $1000 \mathrm{~m}^{2} / \mathrm{g}$ of specific surface area with the highest mesopore volume fraction.

\section{Acknowledgement}

This research was financially supported by the Ministry of Trade, Industry \&Energy(MOTIE), Korea Institute for Advancement of Technology(KIAT) and Honam Institute for Regional Program Evaluation through the Leading Industry Development for Economic Region.

\section{References}

[1] Nguyen LN, Hai FI, Kang J, Price WE, Nghiem LD. Coupling granular activated carbon adsorption with membrane bioreactor treatment for trace organic contaminant removal: Breakthrough behaviour of persistent and hydrophilic compounds. J Environ Manage, 119, 173 (2013). http://dx.doi.org/10.1016/j.jenvman.2013.01.037.

[2] Ahmad AA, Idris A, Hameed BH. Organic dye adsorption on activated carbon derived from solid waste. Desalin Water Treat, 51, 2554 (2013). http://dx.doi.org/10.1080/19443994.2012.749019.

[3] MinakshiM, MeyrickD,AppadooD. Maricite $\left(\mathrm{NaMn}_{1} / \mathrm{Ni}_{1} / \mathrm{Co}_{1} / 3 \mathrm{PO}_{4}\right) /$ activated carbon: hybrid capacitor. Energy Fuels, 27, 3516 (2013). http://dx.doi.org/10.1021/ef400333s.

[4] Lei C, Amini N, Markoulidis F, Wilson P, Tennison S, Lekakou C. Activated carbon from phenolic resin with controlled mesoporosity for an electric double-layer capacitor (EDLC). J Mater Chem A, 1, 6037 (2013). http://dx.doi.org/10.1039/C3TA01638B.

[5] Kim DY, Park SJ, Jung YJ, Kim S. Electrochemical characterization of activated carbon-sulfur composite electrode in organic electrolyte solution. Carbon Lett, 14, 126 (2013). http://dx.doi. org/10.5714/CL.2012.14.2.126.

[6] Harun MK, Yahya MZA, Abdullah S, Chan CH. Qualitative analysis of the effect of polymer solution and suspension properties on the electrospinning of nanocomposite fibers. Adv Mater Res, 686, 65 (2013). http://dx.doi.org/10.4028/www.scientific.net/AMR.686.65.

[7] Patel N, Fernandes R, Gupta S, Edla R, Kothari DC, Miotello A. Co-B catalyst supported over mesoporous silica for hydrogen production by catalytic hydrolysis of Ammonia Borane: A study on influence of pore structure. Appl Catal B, 140-141, 125 (2013). http://dx.doi.org/10.1016/j.apcatb.2013.03.04.

[8] Sun F, Gao J, Zhu Y, Chen G, Wu S, Qin Y. Adsorption of $\mathrm{SO}_{2}$ by typical carbonaceous material: a comparative study of carbon nanotubes and activated carbons. Adsorption, in press (2013). http://dx.doi.org/10.1007/s10450-013-9504-9.

[9] Qin Y, Wang Y, Wang H, Gao J, Qu Z. Effect of morphology and pore structure of SBA-15 on toluene dynamic adsorption/desorption performance. Procedia Environ Sci, 18, 366 (2013). http:// dx.doi.org/10.1016/j.proenv.2013.04.048.

[10] Bellino MG, Golbert S, De Marzi MC, Soler-Illia GJAA, Desimone MF. Controlled adhesion and proliferation of a human osteoblastic cell line by tuning the nanoporosity of titania and silica coatings. Biomater Sci, 1, 186 (2013). http://dx.doi.org/10.1039/ C2BM00136E.

[11] Fierro CM, Gorka J, Zazo JA, Rodriguez JJ, Ludwinowicz J,
Jaroniec M. Colloidal templating synthesis and adsorption characteristics of microporous-mesoporous carbons from Kraft lignin. Carbon, in press (2013). http://dx.doi.org/10.1016/j.carbon.2013.06.012.

[12] Vovk EI, Turksoy A, Bukhtiyarov VI, Ozensoy E. Interactive Surface Chemistry of $\mathrm{CO}_{2}$ and $\mathrm{NO}_{2}$ on Metal Oxide Surfaces: Competition for Catalytic Adsorption Sites and Reactivity. J Phys Chem C, 117, 7713 (2013). http://dx.doi.org/10.1021/jp400955g.

[13] Billemont P, Coasne B, De Weireld G. Adsorption of carbon dioxide, methane, and their mixtures in porous carbons: effect of surface chemistry, water content, and pore disorder. Langmuir, 29, 3328 (2013). http://dx.doi.org/10.1021/la3048938.

[14] Durimel A, Altenor S, Miranda-Quintana R, Couespel Du Mesnil P, Jauregui-Haza U, Gadiou R, Gaspard S. pH dependence of chlordecone adsorption on activated carbons and role of adsorbent physico-chemical properties. Chem Eng J, 229, 239 (2013). http:// dx.doi.org/10.1016/j.cej.2013.03.036.

[15] Song M, Jin B, Xiao R, Yang L, Wu Y, Zhong Z, Huang Y. The comparison of two activation techniques to prepare activated carbon from corn cob. Biomass Bioenergy, 48, 250 (2013). http:// dx.doi.org/10.1016/j.biombioe.2012.11.007.

[16] Bhati S, Mahur JS, Dixit S, Choubey ON. Surface and adsorption properties of activated carbon fabric prepared from cellulosic polymer: mixed activation method. Bull Korean Chem Soc, 34, 569 (2013). http://dx.doi.org/10.5012/bkcs.2013.34.2.569.

[17] Oschatz M, Borchardt L, Senkovska I, Klein N, Leistner M, Kaskel S. Carbon dioxide activated carbide-derived carbon monoliths as high performance adsorbents. Carbon, 56, 139 (2013). http:// dx.doi.org/10.1016/j.carbon.2012.12.084.

[18] Cheng Z, Sherman BJ, Lo CS. Carbon dioxide activation and dissociation on ceria (110): a density functional theory study. J Chem Phys, 138, 014702 (2013). http://dx.doi.org/10.1063/1.4773248.

[19] Youssef AM, Hassan AF, Safan M. Modeling and characterization of steam-activated carbons developed from cotton stalks. Carbon Lett, 14, 14 (2013). http://dx.doi.org/10.5714/CL.2012.14.1.014.

[20] Kong J, Yue Q, Huang L, Gao Y, Sun Y, Gao B, Li Q, Wang Y. Preparation, characterization and evaluation of adsorptive properties of leather waste based activated carbon via physical and chemical activation. Chem Eng J, 221, 62 (2013). http://dx.doi. org/10.1016/j.cej.2013.02.021.

[21] Srenscek-Nazzal J, Kaminska W, Michalkiewicz B, Koren ZC. Production, characterization and methane storage potential of $\mathrm{KOH}-a c t i v a t e d$ carbon from sugarcane molasses. Ind Crops Prod, 47, 153 (2013). http://dx.doi.org/10.1016/j.indcrop.2013.03.004.

[22] Yang J, Qiu KQ. Preparation of activated carbons by $\mathrm{ZnCl}_{2}$ activation from herb residues under vacuum. Carbon, 51, 437 (2013). http://dx.doi.org/10.1016/j.carbon.2012.08.039.

[23] Qie L, Chen WM, Wang ZH, Shao QG, Li X, Yuan LX, Hu XL, Zhang WX, Huang YH. Nitrogen-doped porous carbon nanofiber webs as anodes for lithium ion batteries with a superhigh capacity and rate capability. Adv Mater, 24, 2047 (2012). http://dx.doi. org/10.1002/adma.201104634.

[24] Brunauer S, Emmett PH, Teller E. Adsorption of gases in multimolecular layers. J Am Chem Soc, 60, 309 (1938). http://dx.doi. org/10.1021/ja01269a023.

[25] Barrett EP, Joyner LG, Halenda PP. The determination of pore volume and area distributions in porous substances. I. Computations from nitrogen isotherms. J Am Chem Soc, 73, 373 (1951). http:// dx.doi.org/10.1021/ja01145a126. 